\title{
Accumulation and Translocation of Heavy Metals in Eggplant (Solanum melongena L.) Grown in a Contaminated Soil
}

\author{
Mohamed Ahmed Youssef, Asem Mohamed Abd El-Gawad \\ Department of Soils and Water, Faculty of Agriculture, Al-Azhar University, Assiut, Egypt
}

Email address:

Dr.mayoussef@yahoo.com (M. A. Youssef),_Asem_11111@yahoo.com (A. M. Abd El-Gawad)

\section{To cite this article:}

Mohamed Ahmed Youssef, Asem Mohamed Abd El-Gawad. Accumulation and Translocation of Heavy Metals in Eggplant (Solanum melongena L.) Grown in a Contaminated Soil. Journal of Energy, Environmental \& Chemical Engineering. Vol. 3, No. 1, 2018 , pp. 9-18. doi: $10.11648 /$ j.jeece. 20180301.12

Received: October 18, 2017; Accepted: January 26, 2018; Published: May 1, 2018

\begin{abstract}
A pot experiment was conducted to investigate the effects of the rock phosphate application on accumulation and translocation of heavy metals from the soil to the roots, shoots and fruits of eggplant (Solanum melongena L.) grown in a sewage sludge amended soil contaminated with $\mathrm{Cd}, \mathrm{Pb}$ and $\mathrm{Ni}$ were 30,30 and $60 \mathrm{mgkg}^{-1}$, respectively. The obtained results demonstrated that the sewage sludge application caused a significance accumulation of metals in the fruits of eggplant. The concentrations of these metals in the fruits were in the order of: $\mathrm{Pb}>\mathrm{Cd}>\mathrm{Ni}$. The fruits of eggplant were not safe for the human consumption, because the levels of heavy metals exceeded the permissible limits. These, heavy metals in different parts of eggplant can be ranked in the order of: roots $>$ shoots $>$ fruits, were $\left(\mathrm{mgkg}^{-1}\right)$. The soil-plant transfer factor (TF) showed that the order of uptake of metals by eggplant was: $\mathrm{Cd}>\mathrm{Ni}>\mathrm{Pb}$. This calls for concern especially in the case of $\mathrm{Pb}$ and $\mathrm{Cd}$ which are highly toxic and of no known biological use. Therefore, Eggplant should not be cultivated in the farms and fields which use sewage sludge contaminated with heavy metals as an amendment.
\end{abstract}

Keywords: Translocation, Heavy Metals, Eggplant, Sewage Sludge, Rock Phosphate and Transfer Factor (TF)

\section{Introduction}

Worldwide environmental pollution is continuously increasing. The soil contaminated with heavy metals like lead $(\mathrm{Pb})$, cadmium $(\mathrm{Cd})$, boron $(\mathrm{B})$, nickel $(\mathrm{Ni})$ chromium $(\mathrm{Cr})$, arsenic (As), molybdenum (Mo)...etc., has serious environmental problems since these metals are non-essential and toxic to plants and animals and have significant implications for human being health [1]. Some industrial emissions and agricultural activities due to various inputs such as fertilizers, metal based pesticides, sewage sludge, phosphorus compounds, insecticides, pesticides, fungicides, herbicides, transportation, tools practically increase the heavy metals level in the substrate [2]. The possible introduction of these elements has contributed to the increasing occurrence of heavy metals in the ecosystem through their direct ingestion from contaminated soils, consumption of vegetables grown on the contaminated soils or drinking wastewater that has percolated through such soils. Thereafter, the food chain (soil-plant-human or soil-plant-animal-human) is an increasing human health concern through breakdown of cell membrane lipids due to the increased accumulation of reactive oxygen species [3-9].

Vegetables (eggplant, tomato, cucumber and pepper...etc.) constitute an important part of the human's diet. In addition, they are considered as a potential source of important nutrients, carbohydrates, proteins, and vitamins [10]. Eggplant, (Solanum melongena L.), is one of the most important vegetables worldwide. It ranks the fourth of world vegetable production after tomato, cucumber, and pepper. According to the Food and Agriculture Organization (FAO), a total production of $32,699,078$ million tons of eggplants were produced on an area of $1,957,603$ ha in 2008, more than 4 million tons of eggplants were produced on an area of $1,676,893$ ha in 2009 , and 46.8 million tons worldwide in 2011 [11-13]. In Egypt, eggplant is a common and popular vegetable and a major crop (1.1 million tons) grown in different areas. It is a good source of minerals, like other prominent solanaceous vegetables such as tomato, and hence, it is important for the human nutrition. 
Many studies have reported negative or toxicity effects of the heavy metals. They are poisonous for macro and microorganisms through their direct influence on the biochemical and physiological processes, reducing growth, deteriorating cell organelles, and preventing photosynthesis and in crop plants; they are of great concern due to the probability of food contamination with heavy metals through the soil-root interface [14-15]. Though the heavy metals are not essential for plant growth, they are readily taken up and accumulated by plants in toxic levels causing a toxic damage to cells and tissues as a result of the complex interaction of major toxic ions with other essential or non-essential ions [16-17].

Other sources of anthropogenic contamination (nonpoint) of soils include the applications of organic manures, sewage sludge, and long-term wastewater that cause a great concern. The main source of heavy metals and trace elements in sewage sludge is industrial wastewater and surface water runoff [18-20]. Although sewage sludge is a carrier of nutrients for the plant growth, its continued use over extended periods can have a negative impact on the environment due to content of the polluted organics, such as hormones, antibiotics, endocrine disruptors, and persistent organic pollutants (POP's). as well as toxic low-molecularweight compounds as polychlorinated biphenyls (PCB), polynuclear aromatic hydrocarbons (PAHs) [21]. Heavy metal compounds that are present in the poorly stabilized sewage sludge, may act as chelating agents that cause toxic metals to be mobilized into the soil solution resulting in the accumulation of heavy metals in soils and their translocation to the various of leafy and other vegetable crops under cultivation, with heavy metals levels that exceed permissible limits [22-24].

Eggplant grown on a soil contaminated with heavy metals absorbs and accumulates metals in roots, shoots, and fruit which might be harmful to human and organisms via the food chain [24]. Heavy metals cause versions diseases to human being for example lead causes devastation health such as neurological damage, blood disorder, hypertension and renal impairment [25]. Increasing the heavy metal content in the soil also increases the heavy metal uptake by plants depending upon the soil type, plant growth stage and plant species [26]. Heavy metals absorbed by plant roots may their translocation and easily accumulate into the edible and aerial parts of the vegetables (roots, stems, leaves, fruits and seeds) of the dill, spinach and eggplant with heavy metals. Their content in the different parts of eggplant are arranged as: roots $>$ fruits $>$ stems [27]. The accumulated heavy metals in plant parts depend up on several factors such as plant type, root system, variety, concentrations of heavy metals in the soil and the nature and properties of the soil [28-31].

According to [32] chemical immobilization is an in situ remediation method where inexpensive chemicals are used to reduce contaminant solubility in the soil. Rock phosphate (RP) is used to reduce the bioavailability of the heavy metals $(\mathrm{Cd}, \mathrm{Ni}$, and $\mathrm{Pb})$ [33]. The possible mechanisms for heavy metal immobilization in the soil involve both the surface complication of the heavy metal ions on the phosphate grains and the partial dissolution of the phosphate amendments which precipitate the heavy metal-containing phosphates [3435]. Also, [36] found that the phosphate-based minerals adsorb, chelate, or/and complex heavy metals in soils which they act as effective heavy metal immobilizing materials. Rock phosphate applications increase its the biomass yield and significantly reduce the availability of the heavy metals $\left(\mathrm{Cd}^{2+}, \mathrm{Pb}^{2+}\right.$ and $\left.\mathrm{Ni}^{2+}\right)$ in the soil as well as effectively reduce the bio-accumulation and translocation of these metals in vegetables [37]. Rock phosphate can be used as an economic amendment in heavy metal polluted soils to reduce the contamination risk in surface and subsurface waters and in the same time, it provides the plants with phosphorus [3845].

This study aims to investigate the effects of adding sewage sludge and rock phosphate on the accumulation and translocation of the heavy metals $(\mathrm{Cd}, \mathrm{Ni}$, and $\mathrm{Pb})$ in different organs parts (roots, shoots and fruits) of eggplant, (Solanum melongena L.) grown in a contaminated soil.

\section{Materials and Methods}

A Pot experiment was conducted to investigate the growth and heavy metal uptake by eggplant (Solanum melongena L.) grown on a contaminated soil amended with the rock phosphate and sewage sludge. The soil used in the study was collected from the surface $(0-30 \mathrm{~cm})$ soil of the Agricultural Experimental, Faculty of Agriculture, AL-Azhar University, Assiut, Egypt, which is located at $2712^{-} 16.67^{-} \mathrm{N}$ latitude and $3109^{-} 36.86^{=}$E longitude during the summer season of 2017. Some soil properties of the experimental site were determined according to [46] and they are listed in Table 1.

Table 1. Some soil chemical properties of the experimental site.

\begin{tabular}{|c|c|c|c|c|}
\hline Parameter & & Value & Parameter & Value \\
\hline \multirow{3}{*}{$\begin{array}{l}\text { Particle size } \\
\text { distribution }\end{array}$} & Sand(\%) & 22.28 & \multicolumn{2}{|c|}{ Total heavy metals $\left(\mathrm{mg} \mathrm{kg}^{-1}\right)$} \\
\hline & Silt $(\%)$ & 21.51 & $\mathrm{Cd}$ & 0.73 \\
\hline & Clay $(\%)$ & 56.21 & $\mathrm{~Pb}$ & 9.50 \\
\hline \multicolumn{2}{|l|}{ Texture grade } & Silty clay loam & $\mathrm{Ni}$ & 7.57 \\
\hline \multicolumn{2}{|l|}{ pH Susp. (1:2.5) } & 7.96 & \multicolumn{2}{|c|}{$\begin{array}{l}\text { DTPA-ext. heavy metals } \\
\left(\mathrm{mgkg}^{-1}\right)\end{array}$} \\
\hline \multicolumn{2}{|l|}{ E. $\mathrm{Ce}\left(\mathrm{dSm}^{-1}\right)$} & 0.96 & $\mathrm{Cd}$ & 0.05 \\
\hline \multicolumn{2}{|l|}{ O.M (\%) } & 1.63 & $\mathrm{~Pb}$ & 0.57 \\
\hline \multicolumn{3}{|c|}{ Soluble cations $(\mathrm{cmol} / \mathrm{kg}$ soil) } & $\mathrm{Ni}$ & 0.08 \\
\hline $\mathrm{Ca}++$ & & 0.75 & \multicolumn{2}{|c|}{ Soluble anions ( $\mathrm{cmol} / \mathrm{kg}$ soil) } \\
\hline $\mathrm{Mg}++$ & & 0.68 & CO3-- & --- \\
\hline $\mathrm{Na}+$ & & 0.17 & HCO3- & 0.47 \\
\hline \multirow[t]{2}{*}{$\mathrm{K}+$} & & 0.21 & $\mathrm{Cl}-$ & 0.67 \\
\hline & & & SO4-- & 0.60 \\
\hline
\end{tabular}

*Each value in this Table is the mean of 3 replicates.

The sewage sludge (SS) sample was collected from the sewage water treatment station at Arab-El-Madabegh, Assiut. The rock phosphate (RP) sample as a natural rock was obtained from Mangabad Super phosphate Factory, Assiut City. Some chemical characteristics of the rock phosphate and sewage sludge samples used in the study are presented in Table (2). 
Table 2. Some chemical characteristics of rock phosphate and sewage sludge samples used in the study.

\begin{tabular}{|c|c|c|c|c|c|c|c|c|c|}
\hline \multirow{2}{*}{ Materials } & \multicolumn{3}{|c|}{ Total macro elements $(\%)$} & \multicolumn{3}{|c|}{ Total heavy metal (mg kg-1) } & \multirow{2}{*}{$\begin{array}{l}\text { O.M } \\
(\%)\end{array}$} & \multirow{2}{*}{$\begin{array}{l}\text { E.C (dSm- } \\
\text { 1) }\end{array}$} & \multirow{2}{*}{$\begin{array}{l}\text { pH Susp. } \\
(1: 2.5)\end{array}$} \\
\hline & $\mathbf{N}$ & $\mathbf{P}$ & $\mathbf{K}$ & Cd & $\mathbf{P b}$ & $\mathrm{Ni}$ & & & \\
\hline Rock phosphate & --- & 24.82 & 0.01 & 0.25 & 1.18 & --- & --- & 2.92 & 6.36 \\
\hline Sewage sludge & 3.86 & 1.74 & 0.77 & 117.39 & 956.46 & 503.71 & 48.61 & 5.03 & 8.37 \\
\hline
\end{tabular}

*Each value in this Table is the mean of 3 replicates.

The collected soil, rock phosphate (RP) and sewage sludge (SS) samples were air-dried, crushed with a wooden roller, sieved through a $2 \mathrm{~mm}$ and mixed. Plastic pots having $6 \mathrm{kgs}$ of soil sample were prepared before adding rock phosphate and sewage sludge treatments. Two eggplant seedlings (4-5 leaves) of approximately 25 day-old were transplanted into each pot. The seedlings were irrigated and maintained to in the pots for 5 weeks to observe their hardiness before adding a heavy metal solution the pots. Then, the soil in the pots was artificially contaminated with $\mathrm{Cd}, \mathrm{Ni}$ and $\mathrm{Pb}$ solutions of $\left(3 \mathrm{CdSO}_{4} .8 \mathrm{H}_{2} \mathrm{O}, \mathrm{NiSO}_{4} \cdot 6 \mathrm{H}_{2} \mathrm{O}\right.$ and $\left.\mathrm{PbSO}_{4} \cdot 9 \mathrm{H}_{2} \mathrm{O}\right)$, respectively, which were applied to the pots in three equal doses each 15 days late. The applied levels of $\mathrm{Cd}, \mathrm{Ni}$, and $\mathrm{Pb}$ in the solutions were 30,30 and $60 \mathrm{mg} \mathrm{kg}^{-1}$, respectively.

Eight treatments of: $\mathrm{T}_{1}$ control (non-contaminated), $\mathrm{T}_{2}$ (Cd, Ni and $\mathrm{Pb}), \mathrm{T}_{3}\left(20\right.$ ton $\mathrm{SS} /$ fed.), $\mathrm{T}_{4}(\mathrm{Cd}, \mathrm{Ni}$ and $\mathrm{Pb}+20$ ton $\mathrm{SS} /$ fed. +10 ton $\mathrm{RP} /$ fed.), $\mathrm{T}_{5}(\mathrm{Cd}, \mathrm{Ni}$ and $\mathrm{Pb}+40$ ton $\mathrm{SS} /$ fed. +10 ton $\mathrm{RP} /$ fed.), $\mathrm{T}_{6}(\mathrm{Cd}, \mathrm{Ni}$ and $\mathrm{Pb}+40$ ton $\mathrm{SS} /$ fed. +20 ton $\mathrm{RP} /$ fed.), $\mathrm{T}_{7}(\mathrm{Cd}, \mathrm{Ni}$ and $\mathrm{Pb}+60$ ton $\mathrm{SS} /$ fed. +20 ton $\mathrm{RP} /$ fed.) and $\mathrm{T}_{8}(\mathrm{Cd}, \mathrm{Ni}$ and $\mathrm{Pb}+60$ ton $\mathrm{SS} /$ fed. +40 ton $\mathrm{RP} /$ fed.) were used. The experiment was laid out in a completely randomized design (CRD) with three replication. A supplemental fertilization of $\mathrm{N}, \mathrm{P}$ and $\mathrm{K}$ was applied at $50 \%$ of the recommend level as ammonium nitrate $(33.5 \%$ $\mathrm{N})$, superphosphate $\left(15.5 \% \mathrm{P}_{2} \mathrm{O}_{5}\right)$ and potassium sulphate $\left(48 \% \mathrm{~K}_{2} \mathrm{O}\right)$, respectively; ammonium nitrate was applied at three equal doses.

The total fruit yield per pot was recorded at harvest ( 80 days). At that time root, shoot and fruit samples of eggplant were washed twice using tap water and rinsed using distilled water, oven-dried at $70{ }^{\circ} \mathrm{C}$ ground using a stainless steel mill, passed through a $0.5 \mathrm{~mm}$ sieve and kept for analysis. Heavy metal concentrations in plant samples were estimated by digesting $0.5 \mathrm{~g}$ plant sample with a mixture of $\mathrm{HNO}_{3}$ and
$\mathrm{HClO}_{4}$ of a 5:1 ratio. The digested samples were cooled and filtered through Whatman No.42 filter papers and the volumes were made up to $100 \mathrm{ml}$ using distilled water. The heavy metals were determined using Flame Atomic Absorption Spectrophotometer (FAAS) according to [47]. Translocation factor (TF) of each heavy metal was calculated to evaluates the risk extent and the relative translocation of these metals from the soil to other plant parts (roots and shoots) according [48].

Statistical analysis was carried out using MS Excel and SPSS software, version 15 the means and standard deviations (SD) of each heavy metal were calculated and differences ( $p$ $<0.05$ ) among means were determined using Duncan's Multiple Range Test (DMRT). Pearson's correlation factor (r) for $\mathrm{p} \leq 0.05$ analysis was done to compare concentrations of the heavy metals in the soil and their accumulation in the roots, shoots and fruits.

\section{Results}

\subsection{Yield Components of Eggplant}

\subsubsection{Fruit Yield}

The data illustrated in Table (3) revealed that statistically significant differences in the average fruit yield of the eggplant existed among the treatments. Among the investigated treatments, the application of sewage sludge alone and heavy metals-sewage sludge mixture overcame in increase fruit yield. Moreover, it was clear that the benefit from application of the rock phosphate-sewage sludge mixture was greater than the application of the sewage sludge only. The results showed that all the treatments were positively affected on the fruit yield per pot compared to control $\mathrm{T}_{1}$.

Table 3. Effect of the heavy metals, rock phosphate, and sewage sludge on fruit yield and yield component of Eggplant.

\begin{tabular}{|c|c|c|c|c|c|c|c|}
\hline \multirow{2}{*}{ Treat. } & \multirow{2}{*}{$\begin{array}{l}\text { Fruit yield } \\
\text { (g/pot) }\end{array}$} & \multicolumn{2}{|c|}{ Roots (g/plant) } & \multicolumn{2}{|c|}{ Shoots (g/plant) } & \multicolumn{2}{|c|}{ Fruits (g/plant) } \\
\hline & & Fresh W. & Dry W. & Fresh W. & Dry W. & Fresh W. & Dry W. \\
\hline $\mathrm{T} 1$ & $109.07 d$ & $3.49 \mathrm{e}$ & $0.94 \mathrm{e}$ & $7.31 \mathrm{a}$ & $1.32 \mathrm{a}$ & $43.63 \mathrm{e}$ & $5.34 a$ \\
\hline $\mathrm{T} 2$ & $113.71 d$ & $7.24 \mathrm{e}$ & $1.43 \mathrm{e}$ & $16.22 b$ & $2.63 a$ & $47.38 \mathrm{e}$ & $6.86 \mathrm{a}$ \\
\hline $\mathrm{T} 3$ & $159.20 \mathrm{c}$ & $24.84 f$ & $4.89 \mathrm{f}$ & $48.32 d$ & $7.81 \mathrm{~b}$ & $64.98 \mathrm{~d}$ & $9.65 b$ \\
\hline $\mathrm{T} 4$ & $170.38 \mathrm{c}$ & $27.91 \mathrm{f}$ & $5.84 \mathrm{f}$ & $52.15 d$ & $8.86 \mathrm{~b}$ & $68.05 d$ & $9.86 \mathrm{~b}$ \\
\hline T5 & $213.28 b$ & $47.63 \mathrm{~g}$ & $9.45 b$ & $98.01 \mathrm{f}$ & $15.81 \mathrm{c}$ & $67.77 d$ & $10.06 \mathrm{~b}$ \\
\hline T6 & $220.69 b$ & $49.21 \mathrm{~g}$ & $9.87 \mathrm{~b}$ & $99.32 \mathrm{f}$ & $16.07 \mathrm{c}$ & $89.35 f$ & $12.71 d$ \\
\hline $\mathrm{T} 8$ & $291.59 a$ & $78.17 \mathrm{c}$ & $16.04 \mathrm{a}$ & $157.71 \mathrm{~g}$ & $25.13 d$ & $118.31 \mathrm{~g}$ & $17.82 \mathrm{e}$ \\
\hline
\end{tabular}

Mean values in the same column followed by the same letters are not significantly different according to the Duncan`s multiple range test (P $<0.05$ ).

Sewage sludge applications led to a greater fruit yield at all application levels (20, 40 and 60 ton SS/fed.). The highest fruit yield $(291.59 \mathrm{~g} / \mathrm{pot})$ was obtained with application of treatment $\mathrm{T}_{8}$ which increased the average fruit yield by $166.76 \%$ compared to the control, the applied sewage sludge associated with its enrichment with the plant essential 
nutrients (both macro and micronutrients) that is important for the plant growth. The lowest fruit yield (113.71 g/pot) was recorded for treatment $T_{2}$ which increased the average fruit yield by $4.25 \%$ compared to the control. Some authors mentioned significant differences in the fruit yield of the eggplant between the applied sewage sludge and the control.

\subsubsection{Fresh and Dry Weight of the Plant Parts}

The fresh and dry weights of the various parts (shoots, roots and fruits) of eggplant as affected by the different treatments are given in Table 3 . The result showed that there were significant $(p<0.05)$ variations in the shoots, roots and fruits fresh and dry weight among the applied treatments they were greatly enhanced by sewage sludge application treatment. However, there were no significant $(p>0.05)$ variations by the application rates of rock phosphate with sewage sludge. All treatments increased the fresh and dry weights of the various parts of the eggplant. The application of $\mathrm{T}_{8}$ gave the highest fresh and dry weight biomass in all plant parts; fresh root weight of $78.17 \mathrm{~g} / \mathrm{plant}$, a dry root weight of $16.04 \mathrm{~g} /$ plant, a fresh shoot weight of 157.71 $\mathrm{g} /$ plant, a dry shoot weight of $25.13 \mathrm{~g} /$ plant, a fresh fruit weight of $118.31 \mathrm{~g} / \mathrm{plant}$ and a dry fruit weight of 17.82 $\mathrm{g} / \mathrm{plant}$. Other treatments were affected by heavy metal accumulations in plants due to the high sewage sludge level had a tendency for higher heavy metal accumulation since the plant biomass was increased with increasing the sewage sludge application rate. However, the lowest values of fresh and dry weight of biomass in all plant parts were obtained from $\mathrm{T}_{2}$.

\subsection{Cadmium Contents of the Soil and Eggplant Parts}

The mean total concentrations of cadmium $(\mathrm{Cd})$ in the soil, roots, shoots, and fruits (edible part) of eggplant are given in Table (4). Permissible limits of heavy metals in the soil and vegetables (eggplant) are used in this study including, International guidelines [49-50] standards have been used for the comparison of the results.

\subsubsection{Soil Cadmium Contents}

The concentrations of $\mathrm{Cd}$ in the treated soil samples were generally higher than the permissible limits (PL) except for those $\mathrm{T}_{1}\left(0.75 \mathrm{mg} \mathrm{kg}^{-1}\right)$ and $\mathrm{T}_{3}\left(1.86 \mathrm{mg} \mathrm{kg}{ }^{-1}\right)$ treatments (Table 4) that were lower than the PL of Cd $\left(3 \mathrm{mg} \mathrm{kg}^{-1}\right)$. It is clear that $\mathrm{T}_{2}, \mathrm{~T}_{4}, \mathrm{~T}_{5}, \mathrm{~T}_{6}, \mathrm{~T}_{7}$ and $\mathrm{T}_{8}$ treatments exhibited a higher soil $\mathrm{Cd}$ contents compared to the control of $\mathrm{T}_{1}$ and $\mathrm{T}_{3}$. Their concentrations of soil $\mathrm{Cd}$ were higher than the toxic limit due to the application of $30 \mathrm{mg} \mathrm{kg}^{-1}$ of $\mathrm{Cd}$ in the investigated treatments.

Table 4. Effect of rock phosphate and sewage sludge on soil and eggplant part Cd contents and its transfer factor (T.F).

\begin{tabular}{|c|c|c|c|c|c|c|c|}
\hline \multirow{2}{*}{ Treat. } & \multirow{2}{*}{$\begin{array}{l}\text { Soil Cd } \\
(\mathrm{mg} \text { kg-1) }\end{array}$} & \multicolumn{2}{|c|}{ Plant Cd (mg kg-1) Dry wt. } & \multirow[b]{2}{*}{ Fruits } & \multicolumn{2}{|c|}{ Cd transfer factor } & \multirow[b]{2}{*}{ Shoot - Fruit } \\
\hline & & Roots & Shoots & & Soil - Root & Root - Shoot & \\
\hline $\mathrm{T} 1$ & $0.75 \pm 0.02 \mathrm{f}$ & $0.16 \pm 0.04 f$ & $0.10 \pm 0.02 \mathrm{e}$ & $0.07 \pm 0.01 \mathrm{e}$ & $0.21 \pm 0.05 b$ & $0.66 \pm 0.12 \mathrm{a}$ & $0.65 \pm 0.06 \mathrm{a}$ \\
\hline $\mathrm{T} 2$ & $27.95 \pm 1.15 \mathrm{e}$ & $9.08 \pm 0.83 \mathrm{e}$ & $3.05 \pm 0.33 \mathrm{c}$ & $0.31 \pm 0.04 \mathrm{c}$ & $0.33 \pm 0.03 b$ & $0.34 \pm 0.06 \mathrm{c}$ & $0.10 \pm 0.03 b$ \\
\hline $\mathrm{T} 3$ & $1.86 \pm 0.39 f$ & $1.03 \pm 0.99 \mathrm{a}$ & $5.54 \pm 0.55 \mathrm{a}$ & $0.48 \pm 0.03 \mathrm{a}$ & $0.55 \pm 0.04 \mathrm{a}$ & $0.47 \pm 0.06 b$ & $0.09 \pm 0.01 b c$ \\
\hline $\mathrm{T} 4$ & $30.16 \pm 0.85 d$ & $10.41 \pm 0.87 \mathrm{bc}$ & $4.98 \pm 0.19 \mathrm{ab}$ & $0.18 \pm 0.02 \mathrm{~d}$ & $0.34 \pm 0.02 b$ & $0.48 \pm 0.04 b$ & $0.04 \pm 0.00 \mathrm{ed}$ \\
\hline T5 & $31.24 \pm 0.09 \mathrm{~cd}$ & $9.87 \pm 0.04 \mathrm{~cd}$ & $4.78 \pm 0.31 b$ & $0.33 \pm 0.01 \mathrm{c}$ & $0.32 \pm 0.00 \mathrm{~b}$ & $0.48 \pm 0.03 b$ & $0.07 \pm 0.01 \mathrm{bcd}$ \\
\hline T6 & $31.64 \pm 0.41 b c$ & $8.30 \pm 0.89 \mathrm{e}$ & $2.17 \pm 0.24 d$ & $0.10 \pm 0.02 \mathrm{e}$ & $0.26 \pm 0.03 b$ & $0.26 \pm 0.02 \mathrm{c}$ & $0.05 \pm 0.01 \mathrm{cde}$ \\
\hline $\mathrm{T} 8$ & $33.14 \pm 1.01 \mathrm{a}$ & $10.21 \pm 0.07 \mathrm{acd}$ & $4.83 \pm 0.10 \mathrm{~b}$ & $0.09 \pm 0.01 \mathrm{e}$ & $0.31 \pm 0.01 b$ & $0.47 \pm 0.01 \mathrm{~b}$ & $0.02 \pm 0.00 \mathrm{e}$ \\
\hline PL* & $3-6$ & $0.1-1.5$ & & & nd & nd & nd \\
\hline
\end{tabular}

Mean of $(\mathrm{n}=3) \pm$ Standard Deviation, within column followed by the same letters are not significantly different according to Duncan`s multiple range test $(\mathrm{P}<$ $0.05)$.

* Permissible Limits (PL) Guideline of EU, (2006) and WHO/FAO, (2007).

\subsubsection{Plant Part Cadmium Contents}

The Cd contents of eggplant ranged from 0.16 to 11.14 $\mathrm{mg} \mathrm{kg}-1$ in the roots, from 0.10 to $5.54 \mathrm{mg} \mathrm{kg}^{-1}$ in the shoots and from 0.07 to $0.48 \mathrm{mg} \mathrm{kg}^{-1}$ in the fruits sample (Table 4). The content of $\mathrm{Cd}$ of eggplant fruits in all treatments were above the critical limits $\left(0.1-1.5 \mathrm{mg} \mathrm{kg}^{-1}\right)$ and thus they might be a threat for the consumers. The results showed that the plants absorbed $\mathrm{Cd}$ easier from $\mathrm{T}_{3}$ treatment soil than the control reflecting the ease mobility of $\mathrm{Cd}$ in this treatment. There were significant variations $(\mathrm{p}<0.5)$ in the plant of $\mathrm{Cd}$ contents when the soil was contaminated with sewage sludge.

In all the parts (roots, shoots and fruits) of eggplant, the mean contents of $\mathrm{Cd}$ values are ranked in the order of roots $>$ shoots $>$ fruits. Cadmium in all plant parts reached levels that were higher than the maximum PL $\left(0.1 \mathrm{mg} \mathrm{kg}^{-1}\right)$.

\subsubsection{Transfer and Translocation Factors}

The transfer factor (TF) or mobilization ratio of $\mathrm{Cd}$ from the soil to eggplant roots (TSR) and this translocation factor of $\mathrm{Cd}$ from roots to shoots (TRS) and from shoots to fruits (TSF) were calculated and shown in Table (4). The average TF of Cd content from the soil to eggplant roots (TSR) was found to be in the order of $\mathrm{T}_{3}(0.55)>\mathrm{T}_{4}(0.34)=\mathrm{T}_{7}(0.34)>$ $\mathrm{T}_{2}(0.33)>\mathrm{T}_{5}(0.32)>\mathrm{T}_{8}(0.31)$ these values were higher compared to control $(0.21)$. It could be attributed to their relative translocation rate of $\mathrm{Cd}$ roots of eggplant increased in all treatments with increasing of concentrations of $\mathrm{Cd}$ soil to very high levels of $\mathrm{Cd}$ are accumulated by the plants. In case of the translocation factor from roots to shoots (TRS), it was in the order of $\mathrm{T}_{4}(0.48)=\mathrm{T}_{5}(0.48)>\mathrm{T}_{3}(0.47)=\mathrm{T}_{8}$ $(0.47)=\mathrm{T}_{7}(0.47)>\mathrm{T}_{2}(0.34)>\mathrm{T}_{6}(0.26)$. The TF from shoots to fruits (TSF) exhibited highest values of $0.33,0.10$ and 0.09 $\mathrm{Cd}$ in $\mathrm{T}_{1}, \mathrm{~T}_{2}$, and $\mathrm{T}_{3}$ treatments, respectively. However, the 
lower $\mathrm{TF}$ value from shoots to fruits (0.04) for $\mathrm{Cd}$ was recorded $\mathrm{T}_{4}$ and $\mathrm{T}_{8}$ treatments. Regarding the translocation of heavy metals from roots to the aerial parts of the plants, some heavy metals, such as $\mathrm{Cd}$, move easily in plants and retainer less strongly in the soil and hence they are more mobile than other metals.

\subsection{Lead Contents of the Soil and Eggplant Parts}

The mean concentrations of lead $(\mathrm{Pb})\left(\mathrm{mg} \mathrm{kg}^{-1}\right)$ in the soil as well as in the roots, shoots and fruits of eggplant are given in Table 5.

Table 5. Effect of rock phosphate and sewage sludge on soil and eggplant part $\mathrm{Pb}$ contents and its transfer factor (T.F).

\begin{tabular}{|c|c|c|c|c|c|c|c|}
\hline \multirow{2}{*}{ Treat. } & \multirow{2}{*}{$\begin{array}{l}\text { Soil Pb } \\
\text { (mg kg-1) }\end{array}$} & \multicolumn{3}{|c|}{ Pb (mg kg-1) Dry wt. } & \multicolumn{3}{|c|}{ Pb transfer factor } \\
\hline & & Roots & Shoots & Fruits & Soil - Root & Root - Shoot & Shoot - Fruit \\
\hline $\mathrm{T} 1$ & $10.89 \pm 0.67 \mathrm{~g}$ & $3.12 \pm 0.23 \mathrm{e}$ & $0.88 \pm 0.08 \mathrm{~d}$ & $1.22 \pm 0.05 \mathrm{e}$ & $0.29 \pm 0.03 \mathrm{f}$ & $0.28 \pm 0.02 \mathrm{a}$ & $1.39 \pm 0.13 \mathrm{a}$ \\
\hline $\mathrm{T} 2$ & $55.50 \pm 0.49 \mathrm{e}$ & $30.00 \pm 1.64 d$ & $3.41 \pm 0.32 \mathrm{a}$ & $5.09 \pm 0.30 \mathrm{~b}$ & $0.54 \pm 0.03 \mathrm{e}$ & $0.11 \pm 0.01 b$ & $1.50 \pm 0.18 \mathrm{a}$ \\
\hline T3 & $22.28 \pm 0.50 \mathrm{f}$ & $42.70 \pm 0.81 \mathrm{a}$ & $3.83 \pm 0.27 \mathrm{a}$ & $5.98 \pm 0.24 \mathrm{a}$ & $1.92 \pm 0.02 \mathrm{a}$ & $0.09 \pm 0.00 \mathrm{c}$ & $1.56 \pm 0.05 \mathrm{a}$ \\
\hline $\mathrm{T} 4$ & $58.36 \pm 0.57 \mathrm{~d}$ & $39.09 \pm 0.61 b$ & $1.41 \pm 0.10 \mathrm{c}$ & $1.96 \pm 0.23 \mathrm{~d}$ & $0.67 \pm 0.00 \mathrm{bc}$ & $0.04 \pm 0.00 \mathrm{e}$ & $1.40 \pm 0.24 \mathrm{a}$ \\
\hline T5 & $59.99 \pm 1.45 c$ & $41.00 \pm 1.74 \mathrm{ab}$ & $3.82 \pm 0.20 \mathrm{a}$ & $5.28 \pm 0.55 b$ & $0.68 \pm 0.04 b$ & $0.09 \pm 0.01 \mathrm{c}$ & $1.38 \pm 0.07 \mathrm{a}$ \\
\hline T6 & $61.29 \pm 0.67 b c$ & $35.12 \pm 2.69 \mathrm{c}$ & $1.25 \pm 0.28 \mathrm{~cd}$ & $2.10 \pm 0.22 \mathrm{~d}$ & $0.57 \pm 0.05 \mathrm{de}$ & $0.04 \pm 0.01 \mathrm{e}$ & $1.78 \pm 0.55 \mathrm{a}$ \\
\hline $\mathrm{T} 8$ & $63.20 \pm 0.85 \mathrm{a}$ & $35.21 \pm 0.08 \mathrm{c}$ & $1.17 \pm 0.14 \mathrm{~cd}$ & $2.16 \pm 0.08 \mathrm{~d}$ & $0.56 \pm 0.01 \mathrm{e}$ & $0.03 \pm 0.00 \mathrm{e}$ & $1.85 \pm 0.19 \mathrm{a}$ \\
\hline PL* & $100-300$ & $0.3-5.0$ & & & nd & nd & nd \\
\hline
\end{tabular}

Mean of $(\mathrm{n}=3) \pm$ Standard Deviation, within column followed by the same letters are not significantly different according to Duncan`s multiple range test $(\mathrm{P}<$ $0.05)$.

${ }^{*}$ Permissible Limits (PL) Guideline of EU, (2006) and WHO/FAO, (2007).

\subsubsection{Soil Lead Contents}

The concentrations of $\mathrm{Pb}$ in all treated the soil samples were generally lower than the Permissible Limits of $\mathrm{Pb}(100$ $\left.\mathrm{mg} \mathrm{kg}{ }^{-1}\right)$. On the other hand, in all parts of eggplant, $\mathrm{Pb}$ levels were higher than the PL which is $\left(0.3 \mathrm{mg} \mathrm{kg}^{-1}\right)$. The results clearly exhibited that soil samples treated with $\mathrm{T}_{8}$ and $\mathrm{T}_{7}$ exhibited $\mathrm{Pb}$ contents of 82.55 and $82.77 \%$ above the control, whereas the $\mathrm{Pb}$ contents of $\mathrm{T}_{2}, \mathrm{~T}_{3}$ and $\mathrm{T}_{4}$ treated soil samples were near the control, high concentrations of $\mathrm{Pb}$ in all soil treatments might be due to high contents of $\mathrm{Pb}$ in the soil caused by the application of sewage sludge.

\subsubsection{Plant Part Lead Contents}

In general, the increase $\mathrm{Pb}$ in the parts (roots, shoots and fruits) of eggplant was consistent with the $\mathrm{Pb}$ concentration in the soil. The results showed that lead content of eggplant grown in $\mathrm{T}_{3}$ amended soil was higher than that of the control due to the higher available $\mathrm{Pb}$ concentration in the $\mathrm{T}_{3}$ treated soil higher.

The content of $\mathrm{Pb}$ in the fruit (edible part) of eggplant samples were above the PL and thus it might be a threat for the consumers. The highest $\mathrm{Pb}$ level in the edible part (5.98 $\left.\mathrm{mg} \mathrm{kg}{ }^{-1}\right)$ that is above the PL was recorded for $\mathrm{T}_{3}$ treatment. At the same time, the $\mathrm{Pb}$ concentration in fruits was 2 times higher than the maximum permissible limit; there were significant variations $(\mathrm{p}<0.5)$ in the plant $\mathrm{Pb}$ content when the soil was amended with sewage sludge. Vegetables have greater potential for accumulating $\mathrm{Pb}$ in their edible parts than other crops, due to their higher transpiration rate [25]. In all eggplant parts (roots, shoots and fruits), on the basis of the mean values, the $\mathrm{Pb}$ concentration in the different parts of eggplant can be arranged in the order of roots $>$ fruits $>$ shoots. Lead reached a higher level than that PL. The results showed that the highest concentration of $\mathrm{Pb}$ in eggplant parts was found in the roots.

\subsubsection{Transfer and Translocation Factors}

On the basis of these results, the translocation factor (TF) value allows the estimation of the capacity of the studied plants to absorb $\mathrm{Pb}$ from the soil. It also reflects the quantity and movement speed of $\mathrm{Pb}$ from soil application of various sludge doses to the above-ground parts of plants. In naturally $\mathrm{Pb}$ contaminated soil, the soil to root and root to shoot $\mathrm{TF}$ values increase with decreasing the $\mathrm{Pb}$ concentration in the soil. The TF of $\mathrm{Pb}$ from the soil to root (TSR) showed a higher value (1.92) with $\mathrm{T}_{3}$ treatment. It was lower for all treatments in this soil that could be attributed to their relative transpiration rate of $\mathrm{Pb}$. The lowest TF value of (0.29) was found the control $\left(\mathrm{T}_{1}\right)$. The root to shoot translocation factor (TRS) of $\mathrm{Pb}$ had the highest value $(0.28)$ for $\mathrm{T}_{1}$ and lowest one $(0.03)$ for $T_{8}$. The shoot to fruit translocation factor (TSF) of $\mathrm{Pb}$ was the highest value (1.85) in the plants grown in the $\mathrm{T}_{8}$ treated soil and the lowest TF value (1.38) in those grown in $\mathrm{T}_{5}$ treated soil. [36] indicated that RP can reduce the phytoavailability of $\mathrm{Pb}$ in the soil due to $\mathrm{Pb}$ immobilization. Lead contents of both roots and shoots significantly decreased with increasing the applied level of RP. Regarding the translocation of heavy metals from roots to the aerial parts of the plants, some heavy metals, such as $\mathrm{Pb}$, move easily in plants and retain less strongly in the soil and hence they are more mobile than other metals. In addition, eggplant in this research may be used in the heavy metal phytoremediation because its TF values were higher than 1 , especially in case of shoot to fruit.

\subsection{Nickel Contents of the Soil and Eggplant Parts}

The mean concentrations of nickel (Ni) in the soil as well as in the roots, shoots and fruits of eggplant are shown in Table 6. 
Table 6. Effect of rock phosphate and sewage sludge on soil and eggplant part $\mathrm{Ni}$ contents and its transfer factor (T.F).

\begin{tabular}{llllllll}
\hline \multirow{2}{*}{ Treat. } & $\begin{array}{l}\text { Soil Ni } \\
\text { (mg kg-1) }\end{array}$ & \multicolumn{2}{l}{ Ni (mg kg-1) Dry wt. } & \multicolumn{3}{l}{ Ni transfer factor } \\
\cline { 3 - 8 } & $6.28 \pm 0.28 \mathrm{e}$ & $0.15 \pm 0.03 \mathrm{c}$ & $0.04 \pm 0.01 \mathrm{e}$ & $0.01 \pm 0.01 \mathrm{f}$ & $0.02 \pm 0.01 \mathrm{~b}$ & $0.28 \pm 0.10 \mathrm{a}$ & $0.37 \pm 0.26 \mathrm{c}$ \\
T1 & $34.38 \pm 1.99 \mathrm{c}$ & $3.17 \pm 1.20 \mathrm{~b}$ & $0.25 \pm 0.04 \mathrm{c}$ & $0.07 \pm 0.01 \mathrm{e}$ & $0.09 \pm 0.04 \mathrm{~b}$ & $0.09 \pm 0.04 \mathrm{~b}$ & $0.30 \pm 0.03 \mathrm{c}$ \\
T2 & $8.55 \pm 0.68 \mathrm{~d}$ & $4.82 \pm 1.22 \mathrm{a}$ & $0.36 \pm 0.07 \mathrm{a}$ & $0.19 \pm 0.01 \mathrm{a}$ & $0.57 \pm 0.17 \mathrm{a}$ & $0.08 \pm 0.04 \mathrm{~b}$ & $0.54 \pm 0.07 \mathrm{c}$ \\
T3 & $38.49 \pm 1.32 \mathrm{~b}$ & $2.51 \pm 0.43 \mathrm{~b}$ & $0.32 \pm 0.01 \mathrm{de}$ & $0.12 \pm 0.01 \mathrm{bc}$ & $0.07 \pm 0.01 \mathrm{~b}$ & $0.02 \pm 0.01 \mathrm{~b}$ & $0.37 \pm 0.49 \mathrm{a}$ \\
T4 & $39.12 \pm 1.13 \mathrm{~b}$ & $3.31 \pm 0.38 \mathrm{~b}$ & $0.28 \pm 0.01 \mathrm{bc}$ & $0.09 \pm 0.01 \mathrm{de}$ & $0.08 \pm 0.01 \mathrm{~b}$ & $0.09 \pm 0.01 \mathrm{~b}$ & $0.32 \pm 0.03 \mathrm{c}$ \\
T5 & $38.19 \pm 0.21 \mathrm{~b}$ & $2.95 \pm 0.04 \mathrm{~b}$ & $0.09 \pm 0.02 \mathrm{~d}$ & $0.04 \pm 0.01 \mathrm{f}$ & $0.08 \pm 0.00 \mathrm{~b}$ & $0.03 \pm 0.00 \mathrm{~b}$ & $0.41 \pm 0.12 \mathrm{c}$ \\
T6 & $39.23 \pm 0.45 \mathrm{~b}$ & $3.60 \pm 0.31 \mathrm{~b}$ & $0.31 \pm 0.02 \mathrm{ab}$ & $0.14 \pm 0.02 \mathrm{~b}$ & $0.09 \pm 0.01 \mathrm{~b}$ & $0.09 \pm 0.01 \mathrm{~b}$ & $0.44 \pm 0.06 \mathrm{c}$ \\
T7 & $41.61 \pm 1.33 \mathrm{a}$ & $2.36 \pm 0.23 \mathrm{~b}$ & $0.17 \pm 0.01 \mathrm{de}$ & $0.11 \pm 0.03 \mathrm{~cd}$ & $0.06 \pm 0.01 \mathrm{~b}$ & $0.03 \pm 0.00 \mathrm{~b}$ & $0.65 \pm 0.36 \mathrm{~b}$ \\
T8 & $75-150$ & $0.4-2.5$ & & & nd & nd & nd \\
PL* & & & & & Shoots & \\
\hline
\end{tabular}

Mean of $(n=3) \pm$ Standard Deviation, within column followed by the same letters are not significantly different according to Duncan`s multiple range test $(\mathrm{P}<$ $0.05)$.

* Permissible Limits (PL) Guideline of EU, (2006) and WHO/FAO, (2007).

\subsubsection{Soil Nickel Contents}

The concentrations of $\mathrm{Ni}$ in all treated soil samples were generally lower than the PL of $\mathrm{Ni}\left(75 \mathrm{mg} \mathrm{kg}^{-1}\right)$. The results clearly indicate that the highest soil concentration of $\mathrm{Ni}$ was recorded for $\mathrm{T}_{8}$ treatment which was $84.91 \%$ above the control, high concentrations of $\mathrm{Ni}$ in the soil treatments might be due to high contents of $\mathrm{Ni}$ in the applied sewage sludge. The lowest soil concentration of $\mathrm{Ni}$ was obtained from $\mathrm{T}_{3}$ treatment.

\subsubsection{Plant Part Nickel Contents}

The Ni contents in all parts of eggplant Ni was lower than its $\mathrm{PL}$ which is $\left(0.4 \mathrm{mg} \mathrm{kg}^{-1}\right)$ except $\mathrm{Ni}$ in roots that was higher than the PL. The results also, showed that Ni content in all parts of eggplant that was grown in $\mathrm{T}_{3}$ treated soil was higher than that of the control. [50] studied the impact of sewage sludge on $\mathrm{Ni}$ of the soil, vegetables edible portions. Found the Ni content of the aerial parts of vegetables grown in $\mathrm{T}_{3}$ treated soil was lower than that of the roots it was 13 times above the PL of Ni. In all parts of eggplant, the mean values of $\mathrm{Ni}$ can be arranged in the order of roots $>$ shoots $>$ fruits. Nickel reached a higher level than PL. the highest concentration of $\mathrm{Ni}$ in eggplant parts was observed in the roots.

\subsubsection{Transfer and Translocation Factors}

The translocation factor (TF) of $\mathrm{Ni}$ is an indicator that helps to understand the mobility of $\mathrm{Ni}$ in plants [51]. In this study, all TF values (TSR), (TRS) and (TSF) of eggplant were lower than 1 (Table 6) means that Ni had a low transfer from roots to shoots and from shoots to fruit of eggplant. The TF of Ni for TSR showed a higher value $(0.57)$ for $\mathrm{T}_{3}$ treatment. It had lower values in all investigated treatments due to their relative transpiration rate Ni. It exhibited the lowest value $(0.02)$ in the control $\left(\mathrm{T}_{1}\right)$. A higher value of TSF $(0.28)$ was found in the plant grown on treated soil $T_{1}$ and a lowest value $(0.02)$ in those grown in $\mathrm{T}_{4}$ treated one. The higher value of TSF $(0.65)$ was found in the plants grown on the $T_{8}$ treated soil and lowest one (0.32) was in those grown on $T_{5}$ treated one. [52] studied that phytoremediation potential of three plants grown in contaminated soil and found that all TF values were lower than 1. So, eggplant could be grown on $\mathrm{Ni}$ contaminated soils because due to their lower TF values than 1 in all plant parts. The content of $\mathrm{Ni}$ in eggplant roots samples were above the PL. It may be dangerous for consumption. The highest $\mathrm{Ni}$ content of the roots $\left(4.82 \mathrm{mg} \mathrm{kg}^{-1}\right)$ was recorded for $\mathrm{T}_{3}$ treatment. At the same time, it was 12 times higher than the maximum permissible limits.

\subsection{Evaluation of the Cd, Pb and Ni Contamination in the Studied Soil}

Metals in soils exert a decisive impact on the quality of soil and its use in food production. [53] used the contamination factor (CF) and the degree of contamination (DC) to asses soil contamination through comparing the mean metal concentration of soil to the mean metal background value. Four contamination categories were defined according to [54].

Table 7. The soil contamination factor of $\mathrm{Cd}, \mathrm{Pb}$ and $\mathrm{Ni}$ as affected by rock phosphate and sewage sludge applications.

\begin{tabular}{|c|c|c|c|c|c|c|}
\hline \multirow[b]{2}{*}{ Treat. } & \multicolumn{2}{|c|}{ Evaluation of soil Cd } & \multicolumn{2}{|c|}{ Evaluation of soil $\mathrm{Pb}$} & \multicolumn{2}{|c|}{ Evaluation of soil $\mathrm{Ni}$} \\
\hline & $\begin{array}{l}\text { Contamination } \\
\text { factor }\end{array}$ & $\begin{array}{l}\text { Degree of } \\
\text { contamination }\end{array}$ & $\begin{array}{l}\text { Contamination } \\
\text { factor }\end{array}$ & $\begin{array}{l}\text { Degree of } \\
\text { contamination }\end{array}$ & $\begin{array}{l}\text { Contamination } \\
\text { factor }\end{array}$ & $\begin{array}{l}\text { Degree of } \\
\text { contamination }\end{array}$ \\
\hline $\mathrm{T} 1$ & $0.00 \pm 0.00$ & --- & $0.00 \pm 0.00$ & --- & $0.00 \pm 0.00$ & --- \\
\hline $\mathrm{T} 2$ & $37.12 \pm 1.53 \mathrm{e}$ & $\mathrm{VC}$ & $5.09 \pm 0.05 \mathrm{e}$ & $\mathrm{CC}$ & $5.47 \pm 0.32 \mathrm{c}$ & $\mathrm{CC}$ \\
\hline $\mathrm{T} 3$ & $2.47 \pm 0.52 \mathrm{f}$ & $\mathrm{MC}$ & $2.05 \pm 0.05 \mathrm{f}$ & $\mathrm{MC}$ & $1.36 \pm 0.11 \mathrm{~d}$ & $\mathrm{MC}$ \\
\hline $\mathrm{T} 4$ & $40.06 \pm 1.12 \mathrm{~d}$ & VC & $5.36 \pm 0.05 \mathrm{~d}$ & $\mathrm{CC}$ & $6.13 \pm 0.21 \mathrm{~b}$ & $\mathrm{VC}$ \\
\hline T5 & $41.49 \pm 0.11 \mathrm{~cd}$ & $\mathrm{VC}$ & $5.51 \pm 0.13 \mathrm{c}$ & $\mathrm{CC}$ & $6.23 \pm 0.18 b$ & $\mathrm{VC}$ \\
\hline T6 & $42.01 \pm 0.55 \mathrm{f}$ & $\mathrm{VC}$ & $5.63 \pm 0.06 \mathrm{bc}$ & $\mathrm{CC}$ & $6.08 \pm 0.03 b$ & $\mathrm{VC}$ \\
\hline $\mathrm{T} 7$ & $43.23 \pm 0.85 \mathrm{ab}$ & $\mathrm{VC}$ & $5.73 \pm 0.05 \mathrm{ab}$ & $\mathrm{CC}$ & $6.24 \pm 0.07 \mathrm{~b}$ & $\mathrm{VC}$ \\
\hline $\mathrm{T} 8$ & $44.02 \pm 1.37 \mathrm{a}$ & $\mathrm{VC}$ & $5.80 \pm 0.08 \mathrm{a}$ & $\mathrm{CC}$ & $6.62 \pm 0.21 \mathrm{a}$ & $\mathrm{VC}$ \\
\hline
\end{tabular}

*Mean of $(\mathrm{n}=3) \pm$ Standard Deviation, within column followed by the same letters are not significantly different according to Duncan`s multiple range test $(\mathrm{P}<0.05)$. ** Low contamination $(\mathrm{LC})=\mathrm{CF}<1$, moderate contamination $(\mathrm{MC})=1 \leq \mathrm{CF}<3$, considerable contamination $(\mathrm{CC})=3 \leq \mathrm{CF}<6$ and very high contamination $(\mathrm{VC})=\mathrm{CF} \geq 6$. 
Data in Table (7) show the contamination factor (CF) of $\mathrm{Cd}, \mathrm{Pb}$ and $\mathrm{Ni}$ in all treated soil sample which the $\mathrm{CF}$ of $\mathrm{Cd}$ ranged from 2.47 to 44.02 . In these soil samples, the $\mathrm{CF}$ of $\mathrm{Pb}$ varied from 2.05 to 5.80 and that of $\mathrm{Ni}$ had the range of 1.36 to 6.62 . Therefore, the results clearly showed that the highest contamination degree of $\mathrm{Cd}, \mathrm{Pb}$ and $\mathrm{Ni}$ was found in the T8 treated soil sample.

\section{Discussion}

The data illustrated in Table (3) indicated that the highest fruit yield as the application of the sewage sludge may be its enrichment with the plant essential nutrients that is important for the plant growth. The results are in agreement with [55, 27]. However, the lowest values in all plant parts were obtained when soils contaminated with heavy metals alone. [56] found that the application of 7.5 and $15.0 \mathrm{~kg} / \mathrm{m}^{2}$ of sewage sludge increased the biomass of the above ground plant parts. These results are consistent with those reported by [26, $30-31]$. As well as through the data in Table (4) showed that the vegetables grown in soils contaminated with heavy metals have a greater accumulation of heavy metals than those grown in uncontaminated soils [24]. Sewage sludge applications are considered the main inputs of $\mathrm{Cd}$ to agricultural soils, [57]. These results are comparable with those other earlier studies of [41-42, 44-45].

Cadmium in all plant parts exceeded limits allowed by an increase with 8 times higher than the maximum permissible limits in the roots. It is considered a mobile element, easily absorbed by roots, transported to shoots and uniformly distributed in plants [58]. The results showed that the highest concentration of $\mathrm{Cd}$ in the eggplant was observed in the roots, especially in the soil amended with $\mathrm{T}_{3}$. In this corresponding, the $\mathrm{Cd}$ concentrations in the shoots and roots of various vegetable crops increased with the increasing $\mathrm{Cd}$ concentrations in the growth medium. Moreover, roots $\mathrm{Cd}$ increased more sharply than shoot one. These results agree with those of $[59,27]$. These might be due to the higher mobility of Cd with a natural occurrence in the soil [60]. Also, [36] reported that the addition of rock phosphate (RP) significantly decreased metal contents in both roots and shoots of Lolium prenne L, which may be an indirect evidence for the PR mechanism in immobilizing heavy metals. As for the translocation of heavy metals from roots to the aerial parts of the plants, most heavy metals are quickly moved from roots to shoots and its retainer less strongly in the soil. These results coincide with those of [61-62, 45, 56]. In addition, in this study, eggplant should not be used in the heavy metal phytoremediation because its TF values were lower than 1 and it might not be safe for human consumption. Moreover, [63] indicated that the variations in the transfer factor among different vegetables may be attributed to the differences in the contents of metals in the soil and differences in element uptake by different vegetables.

As for the $\mathrm{Pb}$ in Table (5) it was found that the higher the concentration, roots $>$ fruits, [50] found that the concentration of $\mathrm{Pb}$ in the edible portions of some vegetables grown on sewage sludge amended soil was above the safe limit in $28 \%$ of the samples. The present results are in an agreement with those of $[64,24,66,27]$. The reduction in shoot $\mathrm{Pb}$ concentration may be connected with the plant growth stimulation by $\mathrm{Pb}$ and the subsequent dilution of $\mathrm{Pb}$ in the plant tissue as well as the translocation the inhibition of $\mathrm{Pb}$ from roots to the shoots. [45] showed that rock phosphate is a potential remediation material for $\mathrm{Pb}$ contaminated soils through the significant reduction of bioaccumulated and translocated $\mathrm{Pb}$ in the plant tissues. This finding is comparable with that of [59, 27]. And the translocation of heavy metals from roots to the aerial parts of the plants. These results coincide with those of $[61,65,45$, 56]. Moreover, [63] reported that the variations in the transfer factor among different vegetables may be attributed to the differences in the contents of metals in the soil and differences in element uptake by different vegetables.

Regarding the Ni shown in Table (6) found that the lowest soil concentration of $\mathrm{Ni}$ and aerial parts of eggplant grown in 20 ton SS/fed. treatment. [37] found that the solubilization concentration of $\mathrm{Ni}$ in soils decreased with increasing the added amount of rock phosphate, these results also agree with those of $[5-6,66,7,2,11,17,9]$.

In all parts of eggplant, the mean values of $\mathrm{Ni}$ can be arranged in the order of roots $>$ shoots $>$ fruits. Nickel reached a higher level than PL. the highest concentration of $\mathrm{Ni}$ in eggplant parts was observed in the roots. It may be attributed to the microbial activity around in the roots. Similar results were reported by many scientists $[59,28,25$, 57, 67, 30-31].

It's finally illustrated that the mean concentrations of $\mathrm{Pb}$ in the studied soil samples were lower than those of [49-50] permissible limits (PL) of agricultural soils, the concentrations of $\mathrm{Pb}$ in the eggplant fruits were higher than the plant (PL).

\section{Safety of Consumers}

The PL [49-50] for $\mathrm{Cd}, \mathrm{Pb}$ and $\mathrm{Ni}$ in plants had a range of $0.1-1.5,0.3-5$ and $0.4-2.5 \mathrm{mg} \mathrm{kg}^{-1}$ dry weight, respectively. The results of $\mathrm{Cd}, \mathrm{Pb}$ and $\mathrm{Ni}$ concentrations in fruits were shown in Tables (4, 5 and 6) for all treatments. The highest $\mathrm{Cd}, \mathrm{Pb}$ and $\mathrm{Ni}$ concentrations in the fruits were $0.48,5.98$ and $0.19 \mathrm{mg} \mathrm{kg}^{-1}$ dry weight fruit, respectively in the plants grow in $\mathrm{T}_{3}$ treated soil. Both $\mathrm{Cd}$ and $\mathrm{Pb}$ concentrations in fruits exceeded the standards. Thus, consumers should not eat eggplant grown on $\mathrm{Cd}, \mathrm{Pb}$ and $\mathrm{Ni}$ contaminated soils, cadmium Cd contaminated vegetables are known to result in bone fracture, diarrhea, stomach pains and severe vomiting, reproductive failure, damage of central nervous system and DNA, as well as development.

\section{Conclusion}

Soil contamination associated with sewage sludge 
additions increases the levels of $\mathrm{Pb}, \mathrm{Cd}$, and $\mathrm{Ni}$ intake of the vegetables and soils. Monitoring of heavy metals in vegetables tissues is essential in order to prevent excessive build-up of these metals in the human food chain. This study was conducted to investigate the heavy metals content in a sewage sludge amended soil and eggplant grown on this soil. The results indicated that the $\mathrm{Pb}, \mathrm{Cd}$, and $\mathrm{Ni}$ levels in the sewage sludge amended soil were higher than the safety limits. The levels of $\mathrm{Pb}$ and $\mathrm{Ni}$ in soil samples were lower than the PL but in eggplant, the content of $\mathrm{Pb}$ and $\mathrm{Cd}$ were higher than the permissible limits. It heavy metals may be absorbed directly from sewage sludge whereas their accumulation in soil is relatively slow. The concentration of $\mathrm{Pb}$ and $\mathrm{Cd}$ was more in the roots than fruits. The $\mathrm{Pb}$ and $\mathrm{Cd}$ levels in plant parts were a arranged in the order of roots $>$ shoots $>$ fruits. The lead and cadmium were highly toxic metals and could be accumulated and transferred to the food chain. It is recommended that the retention of the heavy metals by the rock phosphate application in the contaminated soils could reduce their contamination risk in the edible portions of vegetables.

\section{References}

[1] Kanwar, J. S. and Sandha, M. S. 2000. Waste water pollution injury to vegetable crops, a review. Agric. Review., 21(2): 133-136.

[2] Wuana, R. A. and Okieimen, F. E. 2010. Phytoremediation Potential of Maize (Zea mays L.). A Review. Afr. J. Gen. Agric. 6 (4): 275-287.

[3] McLaughlin, M. J., Zarcinas, B. A., Stevens, D. P. and Cook, N. 2000. Soil testing for heavy metals. Commun. Soil Sci. Plant Anal., 31(11-14), 1661-1700.

[4] Singh, R. P. 2001. Heavy metal in soils: sources, chemical reactions and forms. In Geo Environment. Proceedings of 2nd Australia and New Zealand Conference on Environmental Geotechnics: Newcastle, New South Wales'. Eds D. Smith, S. fityus and M. AIlman. 77-93.

[5] Vinit-Dunand, F., Epron, D., Alaoui-Sosse, B. and Badot, P. M. 2002. Effects of copper on growth and on photosynthesis of mature and expanding leaves in cucumber plants. Plant Sci 163(1): 53-58.

[6] Rellan-Alvarez, R., Ortega-Villasante, C., Alvarez-Fernandez, A., Del Campo, F. F. and Hernandez, L. E. 2006. Stress response of Zea mays to cadmium and mercury. Plant Soil, 279: 41-50.

[7] Zhuang, P., McBride, M. B., Xia H., Li, N. and Li, Z. 2009. Health risk from heavy metals via consumption of food crops in the vicinity of Dabaoshan mine. South China Sci., Total Environ. 407: 1551-1561.

[8] Eid, M. A. 2011. Halophytic Plants for Phytoremediation of Heavy Metals Contaminated Soil. J. of American Sci., 7(8):377-382.

[9] Moosavi, S. G. and Mohamd J. S. 2013. Phytoremediation: A review. Adv. Agri. Bio. 1 (1):5-11.
[10] Arai, S. 2002. Global view on functional foods: Asian perspectives. Brit. J. Nutr., 88:139-143.

[11] FAO, 2008. Food and Agriculture Organization of the United Nations (FAO). FAOSTAT, http://faostat.fao.org.

[12] FAO, 2009. Food and Agriculture Organization of the United Nations (FAO). FAOSTAT, http://faostat.fao.org.

[13] FAO, 2011. Food and Agriculture Organization of the United Nations (FAO). FAOSTAT, http://faostat.fao.org.

[14] Bhatti, A. U. and Perveen, S. 2005. Heavy metals hazards in agriculture in NWFP. Proceedings of the First International Conference on Environmentally Sustainable Development. Department of Environmental Sciences, COMSATS Inst. Info. Tech. Abbottabad, Pakistan. pp. 1513-1518.

[15] Sajida, P., Samad, A., Nazif, W. and Shah, S. 2012. Impact of sewage water on vegetables quality with respect to heavy metals in peshawar pakistan. Pak. J. Bot., 44(6): 1923-1931.

[16] Navarro, M. C., Pérez-Sirvent, C., Martínez-Sánchez, M. J., Vidal, J., Tovar, P. J. and Bech, J. 2008. Abandoned mine sites as a source of contamination by heavy metals: A case study in a semi-arid zone. J. of Geochemical Exp., 96 (2-3); 183-193.

[17] Ahmadpour, P., Ahmadpour F., Mahmud, T. M. M., Arifin Abdu, H. S. and Tayefeh, F. 2012. Phytoremediation of heavy metals: A green technology. African J. of Biotechnology, 11(76): 14036-14043.

[18] Alloway, B. J. and Jackson, A. P. 1991. The behavior of heavy metals in sewage sludge-amended soil. Sci. Total Environ., 100, 151-176.

[19] McBride, M. B. 2003. Toxic metals in sewage sludgeamended soils: has promotion of beneficial use discounted the risks?' Advances in Environmental Res., 8:5-19.

[20] Babel, S., Del, M., and Dacera, D. 2006. Heavy metal removal from contaminated sludge for land application: a review, Waste Manage., 26, 988.

[21] Nrgholi, B. 2007. Investigation of the Firozabad wastewater quality-quantity variation for agricultural use. Final report. Iranian Agric. Eng. Res. Institute.

[22] Singh, R. P. and Agrawal, M. 2008. Potential benefits and risks of land application of sewage sludge. Waste Manag, 28: 347-358.

[23] R. M. E. 2010. Regulation of the Ministry of Environment from July $13^{\text {th }}$, R. M. E. on municipal sewage sludge, Dz. U. z 2010 r. Nr 137 poz. 924 (in Polish).

[24] Marshall, F. M., Holden, J., Ghose, C., Chisala, B., Kapungwe, E., Volk, J., Agrawal, M., Agrawal, R., Sharma, R. K. and Singh, R. P. 2007. Contaminated irrigation water and food safety for the urban and periurban poor: www.pollutionandfood. net.

[25] Mapanda, F., Mangwayana, E. N., Nyamangara, J. and Giller, K. E. 2005. The effects of long-term irrigation using water on heavy metal contents of soils under vegetables. Agriculture, Ecosystem and Environment, 107: 151-156.

[26] Farooq, M., Anwar, F. and Rashid, U. 2008. Appraisal of heavy metal content in different vegetables grown in the vicinity of an industrial area. Pak. J. Bot., 40: 2099-2106. 
[27] Roychowdhury, R. and Tah J. 2011. Differential response by different parts of Solanum melongena L. for heavy metal accumulation. Plant Sciences Feed 1 (6): 80-83.

[28] Yusuf, A. A., Arowolo, T. A. and Bamgbose, O. 2003. Cadmium, copper and nickel levels in vegetables from industrial and residential areas of Lagos City, Nigeria. Food and Chemical Toxicology, 41: 375-378.

[29] Bigdeli, M. and Seilsepour, M. 2008. Investigation of metals accumulation in some vegetables irrigated with waste water in shahre Rey-Iran and toxicological implications. AmericanEurasian J. Agric. and Environ. Sci., 4 (1): 86-92.

[30] Naser, H. M., Mahmud, N. U., Sultana, S., Gomes, R. and Rahman, R. 2012. Trace elements content in vegetables grown in industrially polluted and non-polluted areas. Bangladesh J. of Agric., Res., 37: 515-527.

[31] Ajmal K., Shahid, J., Atif, M., Tahir, M., Abid, N. and Abdul, M. 2013. Heavy metal status of soil and vegetables grown on peri-urban area of Lahore district. Soil Environ., 32 (1): 49-54.

[32] Ma, L. Q. and Rao, G. N. 1997. Effects of phosphate rock on sequential chemical extraction of lead in contaminated soils. J. Environ. Qual., 26: 788-794.

[33] Cao, X. D., Ma, L. Q., Rhue, D. and Appel, C. S. 2004. Mechanisms of lead, copper, and zinc retention by phosphate rock. Environ., Pollution. 131, 435-444.

[34] Perrone, J., Fourest, S. and Giffaut, E. 2001. Sorption of nickel on carbonate fluoroapatites. Colloid interface Sci., 239: 303-313.

[35] Mignardi, S., Corami, A. and Ferrini, V. 2012. Evaluation of the effectiveness of phosphate treatment for the remediation of mine waste soils contaminated with $\mathrm{Cd}, \mathrm{Cu}, \mathrm{Pb}$, and $\mathrm{Zn}$. Chemosphere. 86, 354-360.

[36] Zhao, Z., Jiang, G. and Mao, R. 2014. Effects of particle sizes of rock phosphate on immobilizing heavy metals in lead zinc mine soils. J. Soil Sci. Plant Nutr., 14 (2): 143-153.

[37] Irshad, M., Khan, R. U., Jadoon, S., Hassan, A. and Egrinya Eneji, A. 2014. Effect of phosphate rock on the solubility of heavy metals in soils saturated with industrial wastewater. Can. J. Soil Sci. 94: 543-549.

[38] Fayiga, A. O. and Ma L. Q. 2005. Using phosphate rock to immobilize metal in soil and increase arsenic uptake by hyperaccumulator Pteris vittata. Sci. Tot. Environ., 359: 17-25.

[39] Medina, A., Vassilev, N., Berea, J. M. and Azcon, R. 2005. Application of Aspergillus niger-treated agrowaste residue and Glomus mosseaefor improving growth and nutrition of Trifolium repensin a Cd-contaminated soil. J. Biotechnol., 116: 369-378.

[40] Chen, S. B., Zhu, Y. G. and Ma, Y. B. 2006. The effect of grainsize of rock phosphate amendment on metal immobilizationin contaminated soils. J. Hazard. Mater. 134(13): 74-79.

[41] Hasan, H. A. H. 2007. Role of rock phosphate in alleviation of heavy metals stress on Fusarium oxysporum. Plant soil Environ., 53, (1): 1-6.

[42] Chen, S. B., Chen, L., Ma, Y. B. and Huang, Y. Z. 2009. Can phosphate compounds be used to reduce the plant uptake of $\mathrm{Pb}$ and resist the $\mathrm{Pb}$ stress in $\mathrm{Pb}$-contaminated soils. J. of Environ. Sci., 21, 360-365.
[43] Thawornchaisit, U., and Polprasertb, C. 2009. Evaluation of phosphate fertilizers for the stabilization of cadmium in highly contaminated soils. J. of Hazardous Materials. 165, 11091113.

[44] Tang, W. N., Li, Z. A., Qiu, J., Zou, B., Li, N. Y., Zhuang, P. and Wang, G. 2011. Lime and phosphate could reducecadmium uptake by five vegetables commonly grown in South China. Pedosphere. 21(2): 223-229.

[45] Aikpokpodion, P. E., Lajide, L. and Aiyesanmi, A. F. 2012. In situ remediation activities of rock phosphate in heavy-metal contaminated Cocoa Plantation soil In Owena, South Western, Nigeria. Global J. Environ. Res., 6 (2): 51-57.

[46] Page, A. L., R. H. Miller and Keeney, D. R. 1982. Methods of Soil Analysis. $2^{\text {nd }} \mathrm{E}^{\mathrm{dn}}$., Amercen Society of Agronomy, Madison, WI., USA.

[47] Baker, D. E. and Amacher, M. C. 1982. "Nickel, Copper, Zinc and Cadmium", in A. L. Page et al. (Eds), Methods of Soil Analysis, Part 2, Chemical and Microbiological Properties, 2 nd ed., Agron. Monogr. Vol. 9, ASA and SSSA, Madison, WI, U.S.A.

[48] Gupta, S., Nayek, S., Saha, R. N. and Satpati, S. 2008. Assessment of heavy metal accumulation in macrophyte, agricultural soil and crop plants adjacent to discharge zone of sponge iron factory. Environ. Geol., 55; 731-739.

[49] EU. (European Union). 2006. Commission Regulation (EC) No. 1881/2006 of 19 December setting maximum levels for certain contaminants in foodstuffs. Official J. of European Union L., 364:5-24.

[50] WHO/FAO. 2007. Joint FAO/WHO Food Standard Programme Codex Alimentarius Commission $13^{\text {th }}$ Session. Report of the Thirty Eight Session of the Codex Committee on Food Hygiene. Houston, United States of America, ALINORM 07/30/13.

[51] Ondo, J. A., Prudent, P. Menye Biyogo, R., Rabier, J., Eba, F. and Domeizel, M. 2012. Translocation of Metals in Two Leafy Vegetables Grown in Urban Gardens of Ntoum, Gabon. Afr. J. Agric., Res. 7 (42): 5621-5627.

[52] Mohebbi, A. H., Harutyunyan. S. S. and Chorom, M. 2012. Phytoremediation potential of three plant grown in monoculture and intercropping with Date palm in contaminated soil. Intl. J. Agric., Crop Sci., 4 (20): 15231530 .

[53] Hökanson, L. 1980. An ecological risk index for aquatic pollution control A sedimentological approach water Res., 14: 975-1001.

[54] Liu, W. H., J. Z. Zhan. Z. Y. Ouyang, L. Soderlund and G. H. Liu 2005. Impacts of sewage irrigation on heavy metal distribution and contamination in Bejjing. China. Envir. International, 31: 805-812.

[55] Akanbi, W.B., Togun, A.O., Adediran, J.A. and Ilupeju, E. A. O. 2010. Growth, dry matter and fruit yield components of okra under organic and inorganic sources of nutrients. American Eurasian J. of Sus. Agric., 4 (1): 1-13.

[56] Wołejko, E. U., Wydro, R., Butarewicz, A. and Łoboda, T. 2013. Effects of sewage sludge on the Accumulation of Heavy metals in soil and in mixtures of lawn Grasses. Environ. Protection Eng., Vol. 39 (2):67-76. 
[57] Avino, P., Capannesi, G. and Rosada, A. 2008. Heavy Metal Determination in Atmospheric Particulate Matter by Instrumental Neutron Activation Analysis. Microchem. J., 88: 97-106.

[58] Sekara, M., Poniedziaek, J., Ciura, E., Jedrszczyk, S. 2005. Cadmium and Lead Accumulation and Distribution in the Organs of Nine Crops: Implications for Phytoremediation. Polish J. of Environmental Studies 14(4): 509-516.

[59] Moral, R., Gilkes, R. J, Moreno-Caselles, J. 2002. A comparison of extractants for heavy metals in contaminated soils from Spain. Communi. Soil Sci., Plant Ana., 33(1518):2781-2791.

[60] Alam, M. G. M., Snow, E. T. and A. Tanaka. 2003. Arsenic and heavy metal contamination of vegetables grown in Samta village, Bangladesh. The Sci. Total Environ. 308: 83-96.

[61] Garbisu, C. and Alkorta, I. 2001. Phytoextraction: a costeffective plant-based technology for the removal of metals from the environment. Bioresour. Technol. 77 (3), 229-236.

[62] Lokeshwari, H. and G. T. Chandrappa, 2006. Impact of heavy metal contamination of Bellandur lake on soil and cultivated vegetation. Curr. Sci., 91: 622-627.
[63] Zheng, N., Wang, Q. C., and Zheng, D. M. 2007. Health risk of $\mathrm{Hg}, \mathrm{Pb}, \mathrm{Cd}, \mathrm{Zn}$, and $\mathrm{Cu}$ to the inhabitants around Huludao zinc plant in China via consumption of vegetables. Sci. Environ., 383(1-3):81-89.

[64] Merrington, G., and Smernik, R. J. 2004. Cadmium sorption inbiosolids amended soils: results from a field trial. Sci., Environ., 327, 239-247.

[65] Awotoye O. O., Dada, A. C. and Arawomo, G. A. O. 2011. Impact of Palm Oil Processing Effluent Discharging on the Quality of Receiving Soil and Rivers in South Western Nigeria. J. of Applied Sci. Res., 7(2): 111-118.

[66] Naser, H. M., N. C. Shil, N. U. Mahmud, M. H. Rashid and K. M. Hossain. 2009. Lead, cadmium and nickel contents of vegetables grown in industrially polluted and non-polluted areas of Bangladesh. Bangladesh J. Agric., 34: 545-554.

[67] Ahsan, I., Perveen, S., Shah, Z., Nazif, W. and Shah, H. U. 2011. Study on accumulation of heavy metals in vegetables receiving sewage water. J. of the Ch., Soc. of Pakistan 33(2): 220-227. 